\title{
2 Rhodesian state paternalism and the white working-class family, 1930s-1950s
}

\author{
Ivo Mhike
}

\section{Introduction}

The 1930s witnessed Southern Rhodesia's most severe socio-economic problems since colonial occupation in 1890, giving rise to new state social engineering initiatives about family and children's education which influenced policy into the 1960s. The Great Depression engendered a poor and reprobate class of white juveniles whom the state viewed as an ominous sign of the cataclysmic rupture of white settler family and its values. It undermined the capacity of the working class to reproduce itself; white parents were unable to raise children with the skills and character to work for and defend the colony. More broadly, the condition of the white family violated the sustenance of "white standards" of living, the prestige of the white race and the hegemonic discourse of colonial control. "White standards" were discursively constructed in colonial Rhodesia. All whites were expected to live up to the self-proclaimed superior culture by virtue of being white. They were supposed to be better educated than Africans, occupy superior positions in the workplace and be able to access and afford the material goods manufactured for Europeans. Their possessions and behaviour were supposed to be markedly different from that of Africans. The 1929 Children's Protection and Adoption Act provided the framework for state intervention in youth rehabilitation and child welfare programmes for several decades following its promulgation. This followed a stern warning in 1928 from Southern Rhodesia's first female legislator, Ethel Tawse-Jollie, saying that, 'We [the state] cannot rely on parents of this country to do their duty invariably in regard to these children'. State exasperation with white parents to fulfil their duty in regard to their children pushed state policy into paternalism after 1930.

This chapter considers the history of Rhodesian state paternalism towards the white working-class family regarding the upbringing of white children (education and maturity) as part of building a robust colonial white society and preserving empire. The colonial state maintained considerable influence on the white family since the inception of colonial settlement in the 1890s. However, the 1930s saw the emergence of a multidimensional socioeconomic crisis, characterised by high unemployment amongst white youths and the breakdown of the family unit. In response, state policy morphed into a multifaceted, 
intrusive and coercive state welfarism. White settler desire to maintain a multigenerational model of colonial development resulted in state solicitude over the education of white children. This study analyses the establishment of state welfarism under the Children's Protection and Adoption Act (1929) with a bias towards state guardianship in state-run child institutions. State control of white children to provide skills education and mould character for white maturity were key in the reproduction of the white working class and in building a robust colonial white society in Africa.

This study uses the 1929 Children's Law as a lens to understanding the transformation of state ideas about education and maturity for children from poor and "degenerate" backgrounds. In juvenile rehabilitation homes and other land schemes, the Rhodesian government sought to engineer a white youth who was "rural minded"; who was willing to take up jobs in agriculture or became a future farmer. The curriculum at St Pancras's home for delinquent boys, established in the town of Bulawayo in 1936 in response to an upsurge in delinquency cases, reflected the 1930s government thrust of practical skills training for blue-collar jobs. State programmes under the Children's Protection and Adoption Act revealed colonial authorities' anxiety about the development trajectory of white society, and state ideology of preservation was aimed at achieving three main objectives. The first of these was to prepare white children from the lower classes for a social educational model that was responsive to the productive needs of the economy, departing from the elitist educational model for whites which had, hitherto, been used. Secondly, it was to manage those who could not meet white expectation by setting the moral and social tone of white society in line with the state's vision of ideal colonial society. Thirdly, it was to sustain a robust colonial society and consolidate the Empire. Rhodesian white society was ossified to a considerable degree and the family welfare programmes and child rehabilitation were intended to restore the normative values for social cohesion. The state had intrusive powers over white society through the surveillance of the white working-class family and laying out penalties for violations to child rights. In addition, Rhodesian state usurpation of child guardianship aimed at ensuring the proper values in children could be likened to the controversial colonial separation of indigenous children from their parents in Australia and Canada. ${ }^{1}$ In the same way that colonists in the dominions did not want native children to inherit their parents" "savagery", the Rhodesian state wanted to save white children from their parents' "degeneracy".

This chapter reflects on state fears and ideas, and the extent to which it was prepared go in order to preserve a racialised system. The state saw its necessary to act as "parent" to certain groups of whites who failed to meet its expectations. However, by shepherding these groups, the state subverted its own legitimising ideology of white supremacy and minority rule by demonstrating that not all whites were superior and autonomous. This chapter also speaks to broader debates about how states intervened in the lives of children in colonial settings by forcibly removing white children from their parents. 
It was a universal colonial claim that unregulated youth development threatened both national and imperial demise. ${ }^{2}$ In the structuring of white communities and the problem of poor whites in white settlements, particularly in Southern Africa, children were deemed particularly vulnerable to cultural contamination. State officials were anxious about so-called "evil" home influences, which referred to, amongst other things, failure by parents to provide their children with food and shelter, "drunkard" parents, "immoral" mothers living with multiple men, exposure of children to "cultural contamination" (racial mixing of all forms), begging and prostitution. ${ }^{3}$ The years before adulthood made a significant difference in producing either the next generation of responsible citizens, national leaders, heads of family and good mothers, or moral and physical degenerates. ${ }^{4}$ The 1929 law indicated that the state viewed white children not as mere possessions of their parents but as individuals in their own right whose future was inseparable from that of the state and empire.

This study is largely based on the Rhodesian colonial archive housed at the National Archives of Zimbabwe, Harare, generated by various proto-civil organisations such as the Child Welfare Society and government departments, particularly the departments of Education and Social Welfare. The colonial archive is a rich repository of state programmes on poor and "degenerate" families. However, the power relations were so paternalistic that categories like the poor, children, and "degenerates", amongst others, did not have a voice and were often spoken for by the state. This top-bottom structure of the narratives limits our understanding of the views, attitudes and perceptions of these categories of people towards state programmes of rehabilitation and self-preservation. Those who operated on the fringes of state-defined parameters were objects of the state gaze and seldom had a voice. However, these sources are important in that they articulate government programmes and the intended outcomes allow for appraisal of government initiatives.

\section{State and the Rhodesian white settler family, c. 1900-1930}

State paternalism toward the white family was forged in the history and nature of Rhodesian white society. In 1890, Cecil John Rhodes and the British South Africa Company (BSAC), through a British Royal Charter, established commercial interests over the Zimbabwean plateau. In the first two decades of settler colonial occupation, the white population was highly transient and remained so to varying degrees for the duration of the colonial period. ${ }^{5}$ As a response, the company government actively encouraged white immigration and settlement to exploit the natural resources (land and minerals) of the territory. At the turn of the twentieth century, the government encouraged immigration of white women and settlement of families because the Rhodesian pioneers were largely freebooter white males. ${ }^{6}$ Rhodesia aggressively pursued demographic engineering through immigration policies that actively courted Europeans to come and settle permanently north of the Limpopo. ${ }^{7}$ White immigration was politically vital to the state because it sought to stabilise a white population for 
administrative purposes as well as to sustain a sense of nation. ${ }^{8}$ Migration in settler colonialism involved permanent settlement, creating a sense of sameness, and the attempts by the settler or colonist to remake his society in the new place. ${ }^{9}$ In the Rhodesian context, European immigration was a facet of wider economic policy and national development.

The white family unit became an essential tool in developing a specific set of values upon which Rhodesian settler society was based, and the settler state actively assisted in family welfare. For example, Ordinance 19 of 1904 was designed to prevent destitution of and provide for the relief of wives and families (children) that had been deserted. ${ }^{10}$ Rhodesian state policy was designed with a view to encouraging young white families to choose to settle in Rhodesia over other territories of British settlement such as Canada, Australia, New Zealand and South Africa. ${ }^{11}$ There were other regulations that incentivised the settlement of families and child rearing. For example, married white men in the civil service received a family allowance to cushion them from economic hardship because the Rhodesian cost of living was higher compared to that of neighbouring South Africa. ${ }^{12}$ Civil service regulations also encouraged the employment of unmarried women only. A woman was supposed to resign upon marriage to concentrate on her domestic duties, particularly the raising of children. These regulations were inspired by Victorian domesticity, which confined women to the physical space of the home. Rhodesian society regarded domesticity and motherhood as sufficient emotional fulfilment for females. ${ }^{13}$ In colonial societies, women were perceived as mothers of the imperial race, as symbols of moral chastity and beauty, and conduits of good behaviour. ${ }^{14}$ As such, Rhodesian society also shaped women's gender roles for the sustenance of an ideal society and these defined motherhood as key to national and imperial success.

Child bearing and child health were state priorities in Rhodesia. The first white child born in colonial Rhodesia was Cecil John born to the Tullochs of Umtali in August of 1891 and by the 1923 census, the "second generation" of Rhodesians numbered some $8,308 .{ }^{15}$ The colony's post-World War One birth rate improved from 27.85 around 1918 to 31.10 per 1,000 by 1923 . Natural population increase was critical in propagating Rhodesian values and would arrest the transient nature of the white population in the colony. In order to consolidate the improving birth rate, the government appointed a Medical Inspector of Schools for the systematic examination of children to improve child health. The Inspector identified the tropical disease malaria, dental hygiene and eye diseases as constituting a risk to child health. The Medical Inspector suggested the establishment of school clinics and feeding schemes so that there would be no need to hesitate bringing a young family to the country because of health concerns to would-be immigrants. ${ }^{16}$ In view of this fact, the Rhodesian state was solicitous about the welfare of white children with whom the future of the colony rested. The post-1930 period would test the state's resolve in child welfare and the reproduction of white dominance in a colonial setting. 
The colonial education policy was linked to Southern Rhodesia's efforts at creating an international image of itself as a colony conducive to family life by providing a competitive system of education comparable to any in the world. ${ }^{17}$ Colonial education transformed significantly during the first three decades of white settlement. In the 1890s provision of education was the responsibility of religious bodies. The Education Ordinance of 1899 enabled the creation of an Education Department and in 1903 government-aided schools were introduced. ${ }^{18}$ In 1907 some 50 per cent of white children of school-going age were receiving some form of education. ${ }^{19}$ However, by the 1920 s Southern Rhodesia had a relatively well-structured system of schools involving state-aided, state controlled and denominational schools. In 1923, some 6,000 white pupils were in school at an average attendance of 88 per cent. ${ }^{20}$ In 1930 the Southern Rhodesia Compulsory Education Act was passed making white education compulsory for children between the ages of 7 and 15 years.

\section{Unemployment, racial and cultural contamination}

The 1930s and 1940s saw economic insecurity, the imperial ideology of white supremacy, and colonial fears of racial "degeneracy" collide in real time. The honeymoon of relative economic and social stability that Rhodesia had enjoyed since the turn of the century evaporated, giving way to unprecedented white unemployment which exacerbated state fears of white "degeneracy". The Great Depression of the 1930s and the ensuing economic and social shocks transformed the social fabric of Southern Rhodesian society. Thousands - black and white - lost their jobs in industry and commerce due to viability crises, farmers were forced off the land as commodity prices fell, and national income plummeted. The onset of the depression and the fall of commodity prices saw cotton and tobacco farmers moving to maize production to offset losses, but between 1930 and 1931 maize prices also dropped from 10 to 4 shillings per bag. However, the production cost remained at 8 shillings per bag. In addition, Southern Rhodesia's national income fell from \&13.9 million to $£ 8.7$ million between 1929 and 1931. ${ }^{21}$

Even more frightening for Rhodesian authorities, the period raised the spectre of the "poor white" problem. In 1932, of the 21,500 settler wage earners in Southern Rhodesia, 8 per cent or 1,720 were unemployed. ${ }^{22}$ In 1933 , a conservative estimate placed white male unemployment at 830 , of whom 400 were married men. ${ }^{23}$ Rhodesian white male poverty was the source of a strong strain of disillusionment because society perceived them as breadwinning patriarchs whose duty it was to provide for their families and uphold white prestige. Loss of jobs resulted in economic insecurities that created "unwholesome" home and social environments that incubated youth delinquency. ${ }^{24}$

The ranks of the unemployed also included youths who were leaving school and could not find job vacancies. The question about white education was no longer one of access to education because the Compulsory Education Act (1929) had resolved this issue. The pertinent question became the relevance of 
a general education and its suitability and desirability to the changing needs of the economy. ${ }^{25}$ From the 1900 s, white education was elitist and aimed to prepare white youth for the civil service, but by the 1930s the public service could no longer absorb all the school leavers. The colonial economy was no longer a useful place for those generally trained for white-collar jobs. Youths had to prepare for blue-collar jobs if they were to keep the mantle of safeguarding white civilisation and carry the settler's mission in colonised lands. ${ }^{26}$ However, the competitive edge of white youths over Africans was compromised by their lack of practical skills. From the outset, Africans were taught practical skills for manual labour. Statistically, about 369 white pupils left school at the end of 1931 and this figure was far less than the annual average of $700 .{ }^{27}$ The Director of Education speculated that the 1931 figure was lower than usual on account of parents keeping their children in school because there were no job vacancies. $^{28}$ In 1932, some 341 white youths left school and 247 required work. ${ }^{29}$ The remaining 94 (28 per cent) entered higher education or left the colony. By May of 1933, some 91 white youths still required employment. ${ }^{30}$ Such statistics vindicated suggestions that there should be a "weeding out" of children who did not have the capacity to proceed to higher education and fill posts requiring such an education to avoid the state wasting resources on a general higher education. ${ }^{31}$ The 1934 report of the Labour commissioner further emphasised that the school system was producing insufficiently equipped youths and this was reflected in the data relating to unemployed adults. ${ }^{32}$ Sections of white society blamed this development on the calibre of the Rhodesian teacher who was a product of England's public school system who found a rural life and the challenges of mining unattractive. ${ }^{33}$

Unemployment, poverty and lax parental control combined to incubate youths who were not amenable to parental control and some who flouted racial restrictions. White children had to be lifted from the morass in which their parents had sunk if the dream of a multigeneration model of colonial development was to be sustained. Rhodesian state paternalism was rationalised to perform the function of guardian in place of "failed" parents. However, it was underpinned by local and Empire-wide anxieties. In the wake of the First World War, imperial authorities noted with concern the low birth rate and poor health of children. ${ }^{34}$ There was a worry in the British Empire about efficiency and decline marked by the South African War (1899-1902) and to a degree the ravages of First World War and the Spanish influenza. Although "degeneracy" was not defined in physical terms but in terms of astuteness of character and qualities to sustain imperial control, the ravages of war and disease did not go unnoticed. Ideas about imperial decline were particularly worrying for Rhodesia because the colony was trying to boost its population and firmly establish a settler colony predicated on specific values. Rhodesian legislator, Lionel Cripps, had earlier warned that, 'The white men were the aristocrats of this country and it behoved them to keep that position for themselves'. ${ }^{35}$ The state harnessed its coercive apparatus and increase its bare-faced paternalism in order to reproduce appropriate settler values. 
In the harsh economic environment of the 1930s, the Rhodesian state recognised juvenile delinquency as a social problem. Juvenile crime was most suggestive of the erosion of white values and incipient social disarray because white children did not exhibit the "aristocratic" values needed to sustain white dominance. Officials took the correlation of poverty and deviance as the basis for identifying delinquents and potential delinquents. Children from poor families were viewed as potential delinquents because they lived on the fringes of white society and, therefore, did not conform to the ideals of whiteness. In 1931, the director of education observed that poverty amongst whites resulted in parents' failure to provide for their children and such children developed delinquent tendencies with the most common offence being theft. Other offences included malicious injury to property, assault and housebreaking. In particular, delinquency labels were attached to children from large poor families who were in receipt of government rations and considered likely to indulge in delinquent behaviours. ${ }^{36}$ In 1932, representatives from the CID, Department of Education and Department of Justice submitted to the government a document on the incidence of juvenile delinquency. ${ }^{37}$ Although the report did not provide any statistical data, it identified poverty and lax parental control as common denominators in the identified cases. ${ }^{38}$ In this respect, juvenile delinquency was framed as a lower-class white problem and common mischief amongst white children from poor families was likely magnified as a harbinger of delinquency.

Eugenic rhetoric aided the Rhodesian discourses of "degeneracy" and juvenile delinquency which formed the basis for state intervention in the white family. Colonial eugenic thinking manifested itself not in the direct importation of metropolitan practices such as sterilization, but in a translation of the political principles and social values that eugenics implied. Eugenics helped identify a range of roles including gender-specific work and productivity, described in social, medical and psychiatric terms. Applied to colonial Rhodesia, eugenics defined white maturity and how white children should be brought up and with whom they should socialise.

The Rhodesian state also framed white poverty as a harbinger of white social and cultural contamination. Through the influences of social Darwinism, inferior races were believed to have a contaminating effect on superior ones and, in particular, poor whites had to be rescued to preserve the purity and superiority of the white race. ${ }^{39}$ In 1931, the Rhodesian Criminal Investigation Department (CID) at Que Que recommended that Douglas (13) and Ronald (9) be considered for a proposed Industrial School largely because, 'it is well known that these children mix with natives in play, and are not cared for as they might be by their parents who are in receipt of government rations and are in a very poor way (sic).${ }^{40}$ In a similar report from Bulawayo, juveniles Peter and James Quinn were deemed "out of control". However, what worried authorities the most was that, 'they frequent native compounds and return with Bicycles Cigarettes [an African brand] and other articles'. In addition, 'they beg or steal these from natives as they have no money to buy them' ${ }^{41}$ While theft was socially abhorred and legally punishable, Rhodesian authorities regarded stealing from Africans 
as sacrilegious in a colonial context where perceived white superiority was sometimes synonymous with infallibility. Stealing from Africans by a member of a "superior" white race transgressed racial, cultural and legal boundaries of colonial society. In this respect, poverty increased white social indecorum and the Rhodesian state had to protect white children from struggling poor families in order to secure the future of the white race.

\section{The state and child guardianship}

The Children's Protection and Adoption Act of 1929 became a quintessential instrument of state control over the white family. Initially promulgated to align Rhodesian child law with that of South Africa, white unemployment and suggestions of the emergence of a "poor white" problem in post-1930 Rhodesia changed the functional nature of the new law. The law came in handy for the state when white parents could not fulfil their obligation over child welfare. The law consolidated state control over white children by giving the courts the power to remove a child from the custody of its parents where certain offences were committed and passing the parental rights either to a relative or to the state. ${ }^{42}$ This provision protected children against the so-called "evil" home influences, which referred to, amongst other things, parental failure to provide food and shelter, "immoral" mothers living with multiple men and exposure of children to racial and cultural "contamination" through begging and prostitution. ${ }^{43}$ However, being poor was enough of an offence for a parent to lose custody. Furthermore, the law sought to minimise the plight of illegitimate white children by providing a mechanism where their status could be legitimised in relation to their parents in line with British law.

The transfer of guardianship largely targeted poor families. The case of the Van der Zandt family typified state paternalism under the Children's law. This was a large family of seven children whom the authorities declared "poor white" because they were in receipt of government relief. In addition, the family was squatting on a piece of alienated land allocated by the Lands Department. ${ }^{44}$ Officials ruled that 'in their interest and the interests of the state', the Van der Zandt girls Johanna (15) and Aletta (13) ought to be sent to an established institution away from their parents to protect them from a poor home environment. ${ }^{45}$ This resonated with state recommendations for Douglas, Ronald and the Quinn brothers mentioned earlier. Practically, the state had assumed control over these children because it judged the parents unable to bring them up in a proper way that upheld "white standards". Rhodesian white society believed that unregulated female child development increased the likelihood that young women would cross the racial divide in their sexual associations. Interracial sex and miscegenation represented the worst form of racial and cultural contamination in white Rhodesia. For the male child, he had to be trained to become a breadwinning patriarch and support a family.

The term "Children In Need of Care" enshrined in the Children's Law encompassed a broad spectrum of "delinquents" and female children who were 
labelled as children in "Moral Danger" and these were identified through the courts and were housed in certified institutions by the authority of the magistrate. The 1929 law established a probation system, formation of juvenile courts, places of safety, government Industrial Schools and other certified institutions for the broad category of "Children In Need of Care", particularly those with no homes and who were not under proper parental control or were subject to immoral influence. Such children had to be sent to certified institutions until they were 18 years of age. ${ }^{46}$ The Probation and School Attendance Officer Sydney Caley, appointed in 1936, acted as guardian ad litem.

State policy of usurping child guardianship contradicted Rhodesia's decades-old white immigration policy that portrayed the colony as a conducive environment for young families. But in the crisis of the 1930s such radical measures were deemed necessary in order to save white society from imminent collapse. Beginning in 1936 the Southern Rhodesia Education Department operated machinery for dealing with neglected and delinquent children under the age of 16 . This comprised several orphanages, boarding houses (with facilities for clothing indigents and boarding them during holidays), working boys and girls hostels, and a moral welfare home for the senior girls and a home for delinquent boys. By 1939 government-certified institutions for destitute and maladjusted white children included St. Joseph's and Rhodesia Children's Home Orphanage (Salisbury), Daisyfield Orphanage (predominantly Afrikaner), and St Clare's Home for white juvenile mothers (Bulawayo).$^{47}$ There were other institutions operating on government grants which received children through the voluntary committal process. This network of institutions or "Places of Safety" provided alternative home environments and propagated good moral values.

\section{Agricultural training in a state certified institution}

\section{St Pancras home for delinquent boys, 1936-1940}

The 1930s-1950s spawned a precipitous trajectory of "white men and boys who lacked the education, discipline and diligence necessary to raise white families' and these 'were perceived as an internal threat to settler visions of multi-generational success' and a liability to the colonial fiscus. ${ }^{48}$ In particular, the white male child was regarded as the defender of colonial establishment and imperial designs. According to Stephanie Olsen, the white boy had upon his shoulders the safeguarding of civilisation and carried the white settler's mission in colonised lands. ${ }^{49} \mathrm{With}$ problems in industry and commerce, the state sought to produce breadwinning patriarchs by fostering a 'rural-mindedness' in male youth for agriculture sector jobs, providing instruction in elementary engineering, woodwork and metalwork. This would increase the number of whites on the land and create new avenues of youth employment. More broadly, the new educational model was enmeshed with the colony's long-term goal to build a white skills base for future industrial development as well as establishing an 
artisanal class that would serve as a bulwark against the economic mobility of Africans to the higher echelons of the colonial economy. ${ }^{50}$

St Pancras home for delinquent boys was established in 1936 near the town of Bulawayo and was run by the Education Department in partnership with the Church of England. The state intended it to be a hybrid institution which combined behavioural reform and industrial training because boys at St Pancras represented all that the colonial officials feared in white male youths: a calibre of male youth who could not mature to support a family. Rehabilitation started with the very location of St Pancras. The director of education recommended a country location as the ideal environment for juvenile rehabilitation and effective control of delinquents as opposed to an urban one. The urban environment and working-class culture were believed to have a morally corrupting influence on children and a country environment was envisioned as most ideal in the process of rehabilitating the delinquent. ${ }^{51}$ In the case of Victorian Britain, Steadman Jones argues that years of exposure to the decaying urban environment gave rise to a degenerate populace unfit to reach maturity and reproduce its kind. ${ }^{52}$ Indeed, images of social pathology, poverty and deviance in the Empire were linked with theories of urban degeneracy. In addition, the rural location of the rehabilitation institution could well have been a way to break urban delinquency networks. Exposing urban juveniles to an alien country environment would bring them out of their rut of misdemeanour. In this respect, the rural location of the new institution was believed to have a therapeutic effect for juvenile rehabilitation.

Practical subjects were a particular focus at St Pancras because 'the boys ... expressed a loathing for school and they required much patience in teaching, ${ }^{53}$ Secondary education was thrown out of the window and agriculture was a prime subject. In 1938, the institution purchased 14 cows and one bull at a cost of $\mathcal{E}_{111}$, and pig runs were constructed with a view to teaching animal husbandry. ${ }^{54}$ Inmates were also engaged in chicken projects and a dozen animal books were purchased for the library. ${ }^{55}$ In addition, some 25 acres of land were put under the plough for the production of maize, potatoes, beans, corn, cowpeas and sweet potatoes. When T.W. Stead from Natal was appointed as School Master in 1938, the Superintendent at St Pancras wrote, 'He is enthusiastic and reliable and the right man for the job. With his influence, there will be an added emphasis on physical fitness and the practical side of Agriculture' ${ }^{56}$ There was a deliberate effort to hire people with experience in South African reformatory work as South Africa had a longer history of juvenile delinquency and Industrial Schools. In this respect, the Superintendent's enthusiasm about the new appointment indicated the core values of the government programme at St Pancras. The fostering of a 'rural-mindedness' in white youths was a central rehabilitation objective.

However, state efforts were frustrated because the project at St Pancras remained small, drawing no more than a dozen boys for each calendar year. As an industrial school, the institution was also an overall failure because not a single graduate of St Pancras made it into farming. It was equally a failure as a 
reformatory. William Laurent (17) became troublesome and authorities at the institution labelled him an 'evil influence' and danger to others only a year into his four-year committal period at St Pancras. 'Willie' was found in possession of stolen goods including an automatic firearm. In addition, he had sold stolen clothes to Africans on the school premises and attempted to poison the Superintendent with cattle dip. He also bullied and cheated other inmates at games. At their wits' end, the St Pancras Committee and administration sent the boy home to be supervised by his parents until such a time when the Ministry of Internal Affairs found an alternative for him. ${ }^{57}$ William epitomised the colossal failure that St Pancras was in achieving character reform and instilling industrial training in delinquent youths from "degenerate" homes. By 1939, the institution had acquired a bad name for financial mismanagement, low numbers of inmates, and an increasingly negative public opinion, so much so that magistrates were reluctant to commit juveniles, forcing the government to close it down in 1940.

The collapse of the agricultural training at St Pancras reflected the general sentiment in the colony. When the depression began to bite and youth unemployment rose, captains of industry also pinned delinquency and the youth labour crisis on the character of the Rhodesian lad. Appraising the character and stamina of Rhodesian youth as a candidate for employment, Captain W.H. Kimpton of the Motor Traders' Association, described the average youth as 'indolent and imputed, without initiative or ambition', faults he ascribed to 'lack of parental control, poor physique and undue native assistance'. ${ }^{58}$ Although A.J. Somerville, representing Principals of Salisbury Schools, vehemently disagreed with this view, it was endorsed by the representative of the Salisbury Municipality, M.E. Cleveland, who perceived the youths as 'lacking manners' ${ }^{59}$ The Rhodesia Agricultural Union (RAU) also alleged that the 1930s labour shortages were, to some degree, artificial and expressed disappointment at the fact that offers of permanent employment on tobacco farms at $£, 10$ per month with lodgings had been turned down by white youths on the ground that 'this was no suitable reward for the sacrifice of the attraction of town life which it entailed'. ${ }^{60}$ Similarly, Salisbury and Bulawayo experienced difficulty in getting youths to accept work on the mines. ${ }^{61}$ In view of this fact, white youth were ill equipped and unwilling to respond to the demands of the changing colonial economy and the business community did not have confidence in them.

Government officials were also concerned about unemployed youths who drifted into government relief works in road construction and in European Labour Afforestation Operations (ELAO) in Mtao and Stapleford. ${ }^{62}$ In 1934, there were 59 youths of 21 years of age and under at the relief camps. ${ }^{63}$ The basic daily rate of pay in these camps was $3 \mathrm{~s} .6 \mathrm{~d}$., with efficiency pay at $6 \mathrm{~d}$. and $1 \mathrm{~d}$. per day as bonus. ${ }^{64}$ Some made up to $6 \mathrm{~s} .9 \mathrm{~d}$. per day against the cost of meals, which ranged between $1 \mathrm{~s} .6 \mathrm{~d}$. and $1 \mathrm{~s} .9 \mathrm{~d} .{ }^{65}$ However, the government did not consider the money paid in relief works as a wage but a token given to enable the men to maintain themselves. Barring the social stigma associated with being in a Relief Camp, relief works were an attractive option for 
youths who did not have any family to support. However, officials viewed the youths who were unwilling to take up proper jobs for relief work as running the risk of developing a dependency on the state. For example, a young man under 20 years at Stapleford refused an offer of employment at 5 pounds a month and 'all round', and another left work at 10 pounds per month, plus a free servant, vegetables and fruit, as he 'preferred the life' at Stapleford. ${ }^{66}$ This was exacerbated by the fact that some men were pulling their children, some as young as 16 years of age, from school to join them in relief work to supplement family income. ${ }^{67}$ At Umvuma School, it became a habit for youths to leave school and wait until they were old enough to enter relief camps for adult unemployed whites. Such youths could never be relied upon to sustain an industrious life, become breadwinners and maintain family. Relief schemes, therefore, caused idleness and bred indolence. The commissioner of labour lamented that;

It is highly undesirable that a youth, during his most impressionable years, should be permitted to do relief work. . . Quite apart from the influences with which they are brought into contact, the very nature of the work itself makes it undesirable for the uninformed character, offering as it does but little scope....A more important aspect is that the youth is guided into that frame of mind which makes the acceptance of relief work or charity not distasteful. $^{68}$

This calibre of youth, the commissioner claimed, would most certainly grow up to become a poor white. Indeed, the ELAO at Mtao had been established in 1925 to absorb 'unemployables' - a term referring to those who could not keep employment, apparently due to alcoholism, nomadic habits, and inadequate training - and acted as a temporary relief for those men who were unemployed at the time.

One could argue that white youths wanted something very different from the vision of white masculinity which their leaders considered so critical. Being willing to stay in relief camps with a day wage suggests an affinity for a homosocial fraternal environment rather than the white male paternalistic domestic farm head, or even the working-class father. Young 'delinquent' men wanted what elite white men feared. The failure of St Pancras in engineering a youth with 'rural-mindedness' reflected wider state failures at making this model work. The attempted youth settlement scheme would further reveal the limits of the state paternalism over white youths.

\section{Still birth: Rhodesian youth land settlement scheme, 1934-1952}

The government proposed to introduce a youth settlement scheme in 1934 at a time when farmers were the most affected of all occupations. The objectives of the scheme were the provision of an outlet for youths leaving school and 
securing a larger white population on the land. Opponents of the scheme questioned the logic of trying to attract the youth to farming under such difficult circumstances. However, the Agriculture Department insisted that the scheme was designed to nurture the future class of farmers. Rhodesian-born youths (21-25 years), with some form of agricultural training, or those resident in the colony for not less than five years, were eligible for settlement on Crown Land subdivisions, preferably in the Mashonaland Watershed. The farm sizes were pegged at 500-1,000 acres and the settlers would be mandated to adopt mixed farming; dairying, pigs, poultry and general crops. In addition, every farm had to have small fenced paddocks and close rotational grazing of the pastures. These lands would be leased free of rent for a period and those who proved suitable would acquire the land. The Agriculture Department would make advances of up to $\mathcal{E} 400$ for the construction of small buildings, water supplies, dip tanks and stumping of land. These loans would be free of interest and terms of payment would be relatively easy. The Agriculture Department compelled these young farmers to live frugally and would not permit them to get into debt except to the Lands Department and the Land Bank. ${ }^{69}$

The programme targeted lower-class urban whites and children from farming communities who the state felt did not need a high education for non-existent white-collar jobs. However, state ideas were not in harmony with white attitudes towards agriculture as a career path. The white youths' loathing of manual work was sufficiently captured in the common adage "Digging and hoeing are the privilege of "Jim" and "Sixpence" and white boys are not to be degraded by such work'.$^{70}$ Both the youths and their parents had a prejudice against manual occupations which they viewed as 'kaffir work' (manual labour usually done by Africans). Following the collapse of Matopos Farm School in 1927, Hillside Experimental Station closed down by mid-1930 due to high operational costs and very low numbers of youth trainees. ${ }^{71}$ Ironically, Hillside closed at a time when the state gospel of rural-mindedness was reaching a crescendo. It was difficult for the state to encourage youths to take farming as a career because in the 1930s agriculture was one of the worst hit economic sectors. ${ }^{72}$

The settlement programme suffered a lack of funding and low uptake. In 1935, the Land Bank flatly refused to fund the programme highlighting the depressed prospects in the agricultural sector and instead urged the Agricultural Department to concentrate on making the sector more attractive to young Rhodesians for job prospects. ${ }^{73}$ Meanwhile, the number of youths willing to work on farms continued to dwindle. In 1934 the total number of youths placed with farmers was 26, and by 1935 only four of these remained in agricultural employment. Of the remaining 22 , nine reportedly gave satisfactory service to their employers during their employment varying from nine to 12 months; and ten were discharged as unsatisfactory or left their employers dissatisfied with the conditions. There were clear indications in the mid-1930s that there was neither the money nor the appetite for the land settlement programme to take off. The overarching government policy to train and settle young Rhodesians on the land as part of cushioning them from the vagaries of unemployment and 
as a way to increase white settlement on land did not resonate with a society struggling with the loss of its traditional job markets in the civil service, industry and commerce. Even youths from farming communities aspired to get jobs in the urban areas.

The policy of economic nationalism or 'Rhodesia for Rhodesians' which had gained some momentum in the civil services and sectors of industry where Africans were replaced by white teenagers, was failing in agriculture and land settlement. ${ }^{74}$ Indeed, the Rhodesian economy was dependent upon agricultural prosperity and elites in government preferred to have young Rhodesians take up careers in agriculture and become farmers, but with little success. In 1937 the colonial state relaunched an incentivised scheme for the settlement of young white male Rhodesians on farms to commence in $1938 .^{75}$ The new scheme was supposed to be limited to ten settlers who would have completed a two to three-year agricultural training in up-to-date and efficient methods applicable to the colony. The government anticipated that these youths would be settled on private land donated for this purpose and only the successful ones from the trials would get Crown Land, the loan payment period was stretched to 15 years and again the Land Bank was unwilling to fund the scheme. ${ }^{76}$ When the war broke out in 1939 not a single youth had been settled under the scheme. ${ }^{77}$ A good number of unemployed youths and 'delinquents' were enlisted into the Rhodesian army under the 1926 Defence Act. After WWII the land settlement scheme suffered another false start in 1949 and eventually in 1952 there were ten eligible youths, but no land. Much of it had been taken up by the post-war Ex-Servicemen land settlement scheme.

\section{Conclusion}

Through extensive and ambitious social engineering initiatives for the white settler family, the state in Southern Rhodesia tried to redraw the moral boundaries of an ossified white community. Colonial officials articulated an aggressive state paternalism that sought to intervene in the white family and usurp parental authority. New laws allowed the state to transfer legal guardianship of children to the state and the state also arrogated to itself the right to determine the kind of education suitable for the different classes of white children without seeking parental consent. New educational policies, juvenile rehabilitation institutions and other juvenile facilities became instruments of state social engineering which cultivated the values deemed appropriate by the state. Overall, this chapter points readers to Southern Rhodesia's efforts at manufacturing an ideal white society. However, by acting as "parent" for certain groups of whites in colonial society, the state exposed the limits of the colonial discourse of white supremacy. The fulcrum of white minority rule was the perceived white superiority and by shepherding some whites to maintain white expectation, the Rhodesian state was subverting its own legitimising ideology; not all whites were superior or autonomous. Sections of white society had to be hand-held to toe the line in order to preserve colonial racial and social order. 
Colonial social policy designed to homogenise white society had some unintended consequences.

Racial hierarchy and privilege were not simple products of colonial conquest, but were expanded through arduous work by politicians and bureaucrats to protect and expand them. Performance of power became an everyday thing aimed at galvanising both the coloniser and subject to accept the structure of colonial society. This chapter also speaks to debates about the extent of colonial states' intervention in the lives of not only the colonised but also the white communities. The forced removal of children from indigenous families in Australia and Canada is well documented. However, the colony of Southern Rhodesia used a similar model to take legal guardianship from "failed" white parents into its custody. The overarching state goal to reproduce white supremacy for successive generations made it imperative to pursue paternalistic policies and directly determine the future of white children. The state determined that the future (children) of Southern Rhodesia could not be left in the hands of individual parents but rested with the central authority of the state. The Rhodesian case presents one of those exceptional cases in colonial societies where such a model was used to control the children of the white race.

\section{Notes}

1 Paisley, 'Childhood and Race', 240-259.

2 Olsen, 'Adolescent Empire', 19-41.

3 Southern Rhodesia, Children's Protection and Adoption Act (1929).

4 Olsen, 'Towards the Modern Man', 159.

5 Brownell, The Collapse of Rhodesia, 3.

6 Law, Gendering the Settler State.

7 Hancock and Godwin, Rhodesians Never Die, 11.

8 Mlambo, White Immigration into Rhodesia, 12.

9 Belich, 'The Rise of the Anglo World', 53. See also Belich, Replenishing the Earth.

10 Southern Rhodesia Ordinance No. 19 of 1904.

11 On Rhodesian Immigration Policy see Mlambo, White Immigration into Rhodesia.

12 Kirkwood, 'Settler Wives in Southern Rhodesia', 147.

13 Kufakurinani, 'White Women and Domesticity in Colonial Zimbabwe', 144.

14 Bush, 'Gender and Empire', 77-111.

15 Tawse-Jollie, The Real Rhodesia, 229.

16 Ibid., 230, 232.

17 Education Committee, Southern Rhodesia Education Committee Report 1908 (Salisbury, Argus: 1908), 4.

18 Southern Rhodesia Education Ordinance No. 1 of 1903.

19 National Archives of Zimbabwe (hereafter NAZ), SRG 3, Legislative Council Debates, 1907.

20 Gann and Gelfand, Huggins of Rhodesia, 136.

21 Phimister, An Economic and Social History of Zimbabwe, 171-172.

22 Government of Southern Rhodesia, Report on the Unemployment and the Relief of Destitution in Southern Rhodesia (n.p., 1934), 4.

23 Ibid., 5.

24 NAZ, S824/42/2, Government of Southern Rhodesia, Juvenile Affairs Boards, 19321934; Director of Education, Southern Rhodesia to the Secretary, Department of the Colonial Secretary, 3 February 1932. 
25 Summers, 'Boys, Brats and Education', 132-153.

26 Olsen, 'Adolescent Empire', 20.

27 NAZ, S824/42/2, Government of Southern Rhodesia, Juvenile Affairs Boards, 19321934; Director of Education, Southern Rhodesia to the Secretary, Department of the Colonial Secretary, 3 February 1932.

28 Ibid.

29 Government of Southern Rhodesia, Report on Unemployment, 8.

30 Ibid.

31 Southern Rhodesia, Southern Rhodesia Legislative Assembly Debates. Volume 7, 849.

32 Government of Southern Rhodesia, Report on Unemployment, 10.

33 Ibid.

34 Paisley, 'Childhood and Race', 240-241.

35 NAZ, SRG 3, Southern Rhodesia Legislative Council Debates, 9 August 1915, Column 198.

36 NAZ, S824/345/1, Education: European, Asian and Coloured Division: Industrial Schools, 1931-1934, Director of Education to all Magistrates, Circular, 3 July 1931.

37 Government of Southern Rhodesia, Report on Juvenile Delinquency in Southern Rhodesia, December 1935 (n.p., 1935), 1.

38 NAZ, S824/345/1, Education: European, Asian and Coloured Division: Industrial Schools, 20 July 1931-1 February 1934; Inspector of Schools, Bulawayo, to Director of Education, 17 March 1932.

39 Dubow, 'Race, Civilisation and Culture', 5-8.

40 NAZ, S824/345/1, Institutions for Juvenile Delinquents, 20 July 1931-1 February 1934, CID Detective Sergeant, Que Que, to Assistant Magistrate, Que Que, 1 October 1931.

41 NAZ, S824/345/1, Institutions for Juvenile Delinquents, 20 July 1931-1 February 1934, Sergeant, Bulawayo Police Station to Chief Superintendent CID, 16 October 1933.

42 Ibid.

43 Children's Protection and Adoption Act (1929).

44 NAZ, S824/345/1, Institutions for Juvenile Delinquents, 20 July 1931-1 February 1934, Assistant Magistrate Chipinga to the Director of Education, Salisbury, 28 July 1932.

45 Ibid.

46 Children's Protection and Adoption Act (1929).

47 NAZ, S824/346/1, Destitute European and Coloured Children Maintained at Institutions, 1936.

48 Summers, 'Boys, Brats and Education', 132-133.

49 Olsen, 'Adolescent Empire', 20.

50 The Industrial Conciliation Act of 1934 was the key legislation designed to impede African social mobility on the job market. It reserved industrial apprenticeship for whites and removed Africans from the definition of 'employee'.

51 Chisholm, 'Reformatories and Industrial Schools in South Africa', 92.

52 Stedman Jones, Outcast London, 285.

53 NAZ, S824/345/3, Institutions for Juvenile Delinquents, 1937-1939; St Pancras Superintendent report for the period 1 July 1936-31 September 1937, 3.

54 NAZ, S824/345/3, Institutions for Juvenile Delinquents, 1937-1939; Minutes of Meeting of the St Pancras Home Committee Held at Southern Life Offices, 7 October 1938, 1.

55 NAZ, S824/345/3, Institutions for Juvenile Delinquents, 1937-1939; St. Pancras Superintendent, PC Sykes report to the St Pancras Home Committee, 19 May 1938, 1.

56 NAZ, S824/345/3, Institutions for Juvenile Delinquents, 1937-1939; St. Pancras Superintendent's report to the St Pancras Home Committee, 18 May 1938, 1.

57 Ibid.

58 NAZ, S824/42/2, Government of Southern Rhodesia Juvenile Affairs Boards, 19321934: Minutes of the Inaugural Meeting for the formation of a Juvenile Affairs Board, Salisbury, 4 March 1932, 12.

59 Ibid., 13.

60 Ibid. 
61 Government of Southern Rhodesia, Report on Unemployment, 9.

62 Ibid.

63 Ibid., 11.

64 NAZ, S1194/1660/1, Government of Southern Rhodesia, White Labour Afforestation Camp: Mtao Report, Memorandum from Minister of Agriculture to the Department of the Colonial Secretary, 10 December 1930, 1.

65 Ibid., 2.

66 Government of Southern Rhodesia, Report on Unemployment, 16.

67 Ibid., 18.

68 Government of Southern Rhodesia, Report on Unemployment, Extract from Education Commission, Report of the Education Commission, 1929 (Cape Town: Cape Times, 1929).

69 NAZ, S1194/190/23, Settlement of Young Rhodesians on the Land, 1937-1952.

70 NAZ, S1194/198/1, Farm Training for Youths at Mtao and Stapleford: Report of Committee on Unemployment, Relief and Destitution in Southern Rhodesia 1934, 7.

71 NAZ, S1194/190/23, Settlement of Young Rhodesians on the Land, 1937-1952.

72 Ibid.

73 Ibid., Land and Agricultural Bank to Secretary Department of Agriculture and Lands, $15 / 01 / 35$.

74 Machingaidze, 'The Development of Settler Capitalist Agriculture', 255.

75 S1194/190/23, Settlement of Young Rhodesians on the Land, 1937-1952.

76 Ibid.

77 There is a yawning gap in the material on the youth settlement scheme between 1939 and 1949. 